Research Report No. 25/2007

\title{
Why Only the State May Inflict Criminal Sanctions
}

Alon Harel

Follow this and additional works at: http:/ / digitalcommons.osgoode.yorku.ca/clpe

\section{Recommended Citation}

Harel, Alon, "Why Only the State May Inflict Criminal Sanctions" (2007). Comparative Research in Law \& Political Economy. Research Paper No. 25/2007.

http://digitalcommons.osgoode.yorku.ca/clpe/241 


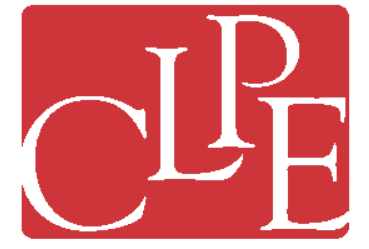

\section{Comparative Research in Law \& Political Economy}

Alon Harel

Why Only the State May Inflict Criminal Sanctions

EDTTORS: Peer Zumbansen (Osgoode Hall Law School, Toronto, Director, Comparative Research in Law and Political Economy, York University), J ohn W. Cioffi (University of California at Riverside), Lindsay Krauss (Osgoode Hall Law School, Toronto, Production Editor) 

CLPE Research Paper 25/2007

Vol. 03 No. 04 (2007)

\title{
Alon Harel \\ Why ONLY ThE STATE MAY INFLict CRIMINAL SANCTIONS
}

\begin{abstract}
Some theorists argue that a justification of criminal punishment presupposes a theory of state power. Although the state is typically assigned the task of inflicting criminal sanctions, the mere fact that the criminal deserves to be punished cannot in itself justify the infliction of punishment by the state, as non-state agents could presumably give people their just deserts.
\end{abstract}

One way of addressing the plea for a theory of state power would be to suggest that state-inflicted sanctions are justified simply on the grounds that the state is more likely than other agents to determine accurately what a wrongdoer justly deserves and to inflict a just sanction on those who deserve it. Hence, the state's role in inflicting criminal sanctions is contingent and, in principle, the state could be replaced by other agents, e.g., private individuals. This hypothesis has given rise to recent calls to reform the state's criminal justice system by introducing privately-inflicted sanctions, e.g., shaming penalties, private prisons or private probationary services.

This paper challenges this view and argues that the agency of the state is indispensable to criminal sanctions in a way that renders the idea of replacing state-inflicted sanctions with privately inflicted sanctions not merely contingently undesirable. Privately-inflicted sanctions sever the link between state's judgments concerning the wrongfulness of the action and the appropriateness of the sanction and the infliction of sufferings on the criminal. When a private individual inflicts punishment she acts on what she and not the state judges to be a sufficient basis for action. Privately-inflicted sanctions for violations of criminal laws are not grounded in the judgments of the appropriate agent, namely the state. It is impermissible on the part of the state to approve a sanction inflicted on an alleged wrongdoer on the basis of such a private judgment. Such an approval grants undue weight to the private judgment of the individual who inflicts the sanction. 
Keywords: criminal sanctions, state agency, private punishment

JEL classification: K42

Author Contact: Alon Harel

Hebrew University Faculty of Law

The Hebrew University, Mt. Scopus

Jerusalem 91905

Israel

Email: msalon@mscc.huji.ac.il 


\title{
WHY ONLY THE STATE MAY INFLICT CRIMINAL SANCTIONS
}

\author{
By Alon Harel*
}

\section{INTRODUCTION}

Criminal sanctions are typically administered by the state. Both the determination of the severity of the criminal sanctions and the actual infliction of the sanctions are typically carried out by the state (via its public officials). Recent developments in the criminal law system are designed to shift some of these powers from the state to individual citizens (or other private entities). Shaming penalties are one paradigmatic example of a shift in the power to determine the severity of sanctions as well as the power to inflict sanctions from the state to private citizens. ${ }^{1}$ Privately run, for-profit prisons are another example, but here only the power to inflict criminal sanctions is transferred from the state to corporate bodies. The victims' rights movement also proposes to shift some of the powers to punish from the state to the victims of crime. A less well-known example of privately-inflicted sanctions is the recent initiative to privatize the probationary system in Britain. ${ }^{2}$ These developments have been thoroughly analyzed by lawyers, economists and sociologists. This paper provides a philosophical perspective on privately-inflicted sanctions.

In this paper I will argue that the recent initiatives to privatize criminal law fail to appreciate the intimate relations between the state and criminal

\footnotetext{
* Alon Harel is the Phillio P. Mizock \& Estelle Mizock Chair in Administrative and Criminal law at Hebrew University.

${ }^{1}$ For contemporary advocates of shaming sanctions, see Dan Kahan, What do Alternative Sanctions Mean? 63 Chicago Law Review 591-653 (1996); Dan M. Kahan, \& Eric A. Posner, Shaming White-Collar Criminals: A Proposal for Reform of the Federal Sentencing Guidelines 42 Journal of Law and Economics 365-391 (1999). In a recent article, Dan Kahan expresses reservations concerning his earlier advocacy of shaming penalties. See Dan Kahan, What's Really Wrong with Shaming Sanctions 84 Texas L. Rev. 2075 (2006).

${ }^{2}$ See Offender Management Bill (http://www.publications.parliament.uk/pa/cm200607/cmbills/009/2007009.pdf).
} 
sanctioning, and that "privatizing" the infliction of criminal sanctions undermines the very foundations of the criminal law system. To the extent that the state issues criminal prohibitions, it should determine the nature and the severity of the sanctions that follow their violation and should itself inflict these sanctions. Criminal prohibitions, it will be argued, are grounded in the state's judgments concerning the wrongfulness of the act. Delegating the power to determine the nature and severity of the criminal sanctions (e.g., by using shaming penalties) or delegating the power to inflict criminal sanctions to private entities (e.g., by establishing private prisons) severs the link between the state's judgments concerning the wrongfulness of the act and the determination of the severity of the sanction or the infliction of the sanction. This link, it will be argued, is indispensable and it is impermissible on the part of the state to authorize the infliction of sanctions in the absence of such a link.

In the Grammar of Criminal Law, George Fletcher defends the view that there is an intimate relation between criminal law and the state:

The distinction between political and moral theory is critical to the argument. Some writers today use the term 'moral' so broadly that their usage obfuscates the important distinction between the state's acting legitimately and individuals acting morally. The political addresses the power and prerogatives of state officials - that is, of human beings cast into a particular role of enforcing criminal prohibitions. The moral focuses primarily on the lives of individuals, both in their personal flourishing and in their relationships with other individuals.

An example of the kind of the argument I seek to avoid is the conventional claim about desert. The argument goes like this. Some people - really bad people like Adolph Eichmann or Slobodan Milosevic-deserve to be punished. Because they deserve a certain consequence, it follows that the state is justified in delivering it. This is a non sequitur....Missing are the critical premises first that is the business of the state rather than of God (or the victim or the victim's family) to punish the offender...Just because the offender might deserve punishment, it does not follow - without an appropriate theory of state power- that the state should assess the degree of 
deserved punishment and use its power to impose it on the offender. The quick assumption that the state is entitled to punish offenders who 'deserve' it is one of the unfortunate banalities of criminal law in our time. ${ }^{3}$

Fletcher believes that only a theory of the state can provide an adequate explanation of why criminal sanctions should be inflicted by the state. A theory of criminal law must be able to explain why the state (rather than other agents) is in charge of inflicting sanctions. Moral theorists in general and desert theorists in particular, Fletcher argues, do not meet this test and thus fail to justify the existence of a state-inflicted scheme of criminal sanctions.

This conclusion, however, is too hasty. The fact that criminal sanctions happen to be state-inflicted does not imply that a justification for inflicting criminal sanctions presuppose a theory of the state. Arguably the political legitimacy of the state rests on its success in inducing moral behavior on the part of individuals. The success of the state in inducing moral behavior could be regarded as a sufficient justification for assigning the power to inflict sanctions to the state. If this is the case, no theory of state power is necessary, since criminal sanctions for wrongdoing do not have to be inflicted by the state. It is merely a coincidence that the state happens (sometimes or even often) to be the agent that is the most capable of inflicting sanctions. Consequently, criminal sanctions should be inflicted by private individuals when these individuals are better placed or can more effectively inflict them.

Theorists who uphold the view that criminal law could be justified without reference to the agency of the state can thus easily address Fletcher's call for a justification of state-inflicted criminal sanctions. On this view, criminal sanctions should be administered by the institution that is the most likely to determine accurately what wrongdoers justly deserve and to inflict the just punishment successfully (or efficiently). The rationale underlying criminal sanctions (and the criteria for determining the severity of the sanction) can thus be fully accounted for without reference to the

3 George Fletcher, The Grammar of Criminal Law: American, Comparative and International vol. 1 pp. 226-7 (Oxford University Press, 2007). 
agent who is assigned the task of inflicting them. Once the rationale for inflicting sanctions has been identified, the theorist should seek the agent who is most likely to succeed in executing this task. Criminal sanctioning is therefore ultimately a task in search of an appropriate agent. So, while Fletcher is right in pointing out that a complete justification of criminal law requires a justification for a state-inflicted scheme of criminal sanctions, such a justification is ultimately founded on instrumental or pragmatic reasons, e.g., the distinctive ability of the state to identify what just desert is and to inflict it successfully or more efficiently than other agents. Such a justification sharply separates the question of what the rationale of criminal punishment and the criteria for determining its appropriateness are and the question of who the agent in charge of administering the sanctions should be. The answer to the latter question can only be answered once the former question concerning the rationale underlying criminal punishment and the criteria for determining the appropriate sanction have been addressed.

While Fletcher raises an important challenge to desert theorists, his analysis fails to investigate whether desert theorists could address this challenge. This paper is an attempt to fill this gap and establish that the state is not merely a means for inflicting deserved suffering on criminals. In fact, I will argue that state-inflicted sanctions are fundamentally different from privately-inflicted sufferings on the guilty. Under this view, the replacement of the state with other agents is not merely impractical or contingently undesirable. Rather, the agency of the state is necessary for the justified infliction of criminal punishment. Establishing a system of privately-inflicted criminal sanctions in fact challenges some of the most fundamental convictions underlying the criminal law system. To the extent that the state prohibits certain sorts of conduct, it is the state and the state alone which ought to administer sanctions for the violations of these prohibitions. A full understanding of the normative justification for criminal sanctions requires an understanding of the indispensability of the agency of the state to the legitimacy of the criminal law system.

Section II starts by defining what I mean by "criminal sanctions", "privately-inflicted sanctions" and "state-inflicted sanctions." Then it differentiates between three types of justifications for state-inflicted criminal sanctions: instrumental justifications, the normative preconditions justifications and state-centered justifications. Section III provides 
arguments in favor of an "integrationist" state-centered justification. It argues that the practice of inflicting sanctions for wrongdoing is an integral part of other duties and powers that the state has. The appropriateness of sanctions and their success in achieving their goals depends on their being integrated into other spheres of the state's activity. Most importantly, inflicting criminal sanctions presupposes that the state forms a judgment with respect to the wrongfulness of the act and the appropriateness of the sanction. Privately-inflicted sanctions, it will be argued, do not reflect the state's judgment concerning the wrongfulness of the act or the appropriateness of the sanction. The infliction of these sanctions severs the link between the state's judgments concerning the wrongfulness of the act and the appropriateness of the sanction or the infliction of the sanction. Section IV investigates the normative implications of the "integrationist justification" for the state's power to inflict sanctions and argues that the integrationist justification casts doubts on the legitimacy of some contemporary punitive practices such as shaming penalties and private prisons.

\section{WHY STATE-INFLICTED CRIMINAL SANCTIONS?}

Prior to examining the three types of justifications for state-inflicted criminal sanctions, I will explain what I mean by criminal sanctions and by state-inflicted and privately-inflicted sanctions.

The fact that one of the characteristic features of criminal sanctions is that they are administered by the state may generate a suspicion that the stateinflicted nature of criminal sanction is not normatively required for the justified infliction of these sanctions but simply part of the definition of criminal sanctions. Thus, privately inflicted sanctions are not illegitimate; instead they simply ought not to be labeled "criminal”. Rebutting this suspicion and establishing a normative argument against privatelyinflicted criminal sanctions requires characterizing criminal sanctions in a way which is independent of the agent who inflicts these sanctions.

Following HLA Hart, I will characterize criminal sanctions as sanctions which involve "pain or other consequences normally considered unpleasant" which are inflicted upon "an actual or supposed offender for his offence" and which must also be imposed for "an offence against legal 
rules". 4 There is however an additional component not explicitly mentioned by Hart which must be stressed: the nature of the remedy. It is obvious that not all unpleasant consequences triggered by violation of a legal rule should be classified as punishment. Tort liability for negligence per se, based on the violation of a statutory norm, could meet this test. ${ }^{5}$ Yet tort liability differs from criminal liability in that the remedy is typically compensatory rather than punitive.

There are of course cases in which the state inflicts pain or other unpleasant consequences that are not characterized as criminal punishments. The state deports aliens, expatriates individuals under extreme circumstances and impeaches presidents for wrongful behavior. ${ }^{6}$ None of these acts is categorized as a criminal sanction. The arguments provided below as to why the state rather than private agents ought to have the power to inflict criminal sanctions may apply to some of these cases even if they are not traditionally categorized as criminal. However, given the fact that criminal law is a paradigmatic case involving punitive measures triggered by violations of state prohibitions, I shall use the term criminal sanctions to refer to all these punitive measures even if they are not traditionally classified as criminal.

The distinction between state-inflicted sanctions and privately-inflicted sanctions also requires some clarification. State-inflicted sanctions are sanctions administered by state officials in their capacity as state officials. Privately-inflicted sanctions are inflicted by private entities. The privatelyinflicted sanctions which are the target of my critique are those and only those sanctions inflicted by individuals (or other private entities) at the encouragement, or initiative of the state. Thus, it is not claimed here that it is impermissible for individuals to condemn convicted offenders on the

4 See HLA Hart, Prolegomenon to the Principles of Punishment in Punishment and Responsibility: Essays in the Philosophy of Law 1, 4-5 (Clarendon Press, Oxford, 1968).

5 The part of the civil law bearing the strongest resemblance to the criminal law is the law of tort. Consequently textbooks of criminal law often start by differentiating between criminal law and tort law. See, e.g., Glanville Williams, Textbook of Criminal Law 25 (London, Stevens \& Sons, $2^{\text {nd }}$ ed., 1983)

6 These are the examples provided by George Fletcher, Rethinking Criminal Law 412 (Little, Brown and Company, Boston 1978) 
basis of a judgment that criminals are evil, or that they ought to suffer etc. Instead, what is impermissible is for the state to hand over the infliction of sanctions to private individuals who inflict the sanctions on its behalf.

One might object here that once the state hands over to an individual or a private entity the power to inflict a sanction, the sanction thereby becomes a state-inflicted sanction. From this it would follow that it is conceptually impossible to inflict a state-approved privately-inflicted sanction. This objection is based on a misunderstanding. To qualify as a state-inflicted sanction, the sanction must be inflicted by a state official. An individual who is called upon "to shame" an offender or a private corporation that is hired to run a prison does not thereby become an official of the state and, consequently, the sanctions inflicted by it are privately-inflicted sanctions. To qualify as a state-inflicted sanction, the agent inflicting it must be an agent who is morally barred from acting on the basis of its own independent judgments, e.g., a judge or a prison guard. In contrast, a private individual who is called upon to shame an offender or a corporation which is hired to run a prison are private entities and the sanctions they inflict are therefore privately-inflicted sanctions.

I will now turn to the description of three types of justifications for stateinflicted criminal sanctions. Under the first type of justifications - the instrumental justifications - the state is the appropriate agent for inflicting criminal sanctions simply because it is deliberative and impartial. As such, it is the most qualified to determine what the just (or appropriate) punishment is and to inflict it on those who deserve it. In principle, the infliction of criminal sanctions could be performed by other, non-state agents; and, furthermore, if circumstances change, it is possible that institutions other than the state should (wholly or in part) replace the state. Under the second type of justifications - the normative precondition justifications - the infliction of criminal sanctions by the state achieves goals which, in principle, could be fully realized through the infliction of sanctions by private agents. Yet, in contrast to the instrumental justifications, there are normative constraints that preclude the infliction of sanctions by agents other than the state. In other words, although the agency of the state is not essential to the success of criminal sanctions, it is a non-contingent normative precondition for the just infliction of criminal 
punishment. $^{7}$ Finally, under the third type of justifications - the statecentered justifications - the power to inflict criminal sanctions is an agentdependent power - a power which can be successfully exercised only by the state. State-inflicted sanctions are designed to realize goals or perform tasks which cannot, in principle, be performed successfully by private institutions or individuals acting on their own. There is a fundamental difference between state-inflicted criminal punishment and suffering inflicted on the guilty by other agents. For this reason criminal sanctions can only be carried out by the state.

This classification shows clearly what the controversy between theories of punishment involves. Some theories regard the state's involvement in punishment as purely instrumental and, consequently, assert that the agency of the state is not necessary for the justifiability of criminal sanctions. Other theories perceive the power to punish as inherently belonging to the state and thus as indispensable for the justifiability of criminal sanctions.

The first type of justifications - instrumental justifications - is premised on the idea that punishment serves important societal goals that could in principle be realized by other non-state agents. However, the state is seen as more capable or better placed to create the institutions and/or sustain the practices which guarantee that punishment is imposed in accordance with the gravity of the offence. A variant of this argument is that stateinflicted sanctions are justified because the state's costs in establishing the relevant institutions or sustaining them are lower than that of other agents.

\footnotetext{
7 Asserting that the agency of the state is a "non-contingent normative precondition for the just infliction of punishment" raises questions concerning the nature and the strength of this normative precondition. The normative precondition justification would not preclude the possibility that there may be circumstances under which non-state agents can justly inflict criminal sanctions. Yet, the normative preconditions justification maintains that, under normal conditions, there are central features of the state that make it the only agent which can inflict criminal sanctions. Radical transformation of the state or of other agents may open the possibility that other agents would justly inflict criminal sanctions. The conditions which could justify such a change ought to be more extreme than those which would justify such a change under the instrumental view. A simple change in the costs of privately-inflicted sanctions or in the deliberative powers of the state or private agents would not suffice to justify transferring the power to inflict sanctions from the state to private agents.
} 
A well known proponent of the view that the state is better capable of determining the appropriate severity of sanctions is John Locke who believed that:

To this strange doctrine, viz. That in the state of nature, every one has the executive power of the law of nature, I doubt not but it will be objected, That it is unreasonable for Men to be Judges in their own Cases, that Self-Love will make Men partial to themselves and their Friends. And on the other side, that Ill Nature, Passion and Revenge will carry them too far in punishing others. And hence nothing but Confusion and Disorder will follow, and that therefore God hath certainly appointed Government to restrain the partiality and violence of men. I easily grant, that Civil Government is the proper Remedy for the inconveniencies of the State of Nature, which must certainly be Great, where Men may be judges in their own Case, since 'iis easilt to be imagined, that he who was so unjust as to do his Brother an Injury, will scarce be so just as to condemn himself for it. ${ }^{8}$

According to Locke, the state should be empowered to inflict sanctions on those who transgress the laws of nature, because the state is less partial than alternative agents in its treatment of offenders and consequently less likely to inflict inappropriate sanctions. In contrast, when individuals are called upon to inflict sanctions on their friends, they are likely to inflict sanctions that are too light. In other cases, motives of vengeance may induce individuals to inflict sanctions that are excessive. Interestingly law and economics scholars often endorse a similar view. In their view, punishment should be supplied by the state because the infliction of sanctions involves a collective action problem. ${ }^{9}$ The individual who inflicts a sanction has to bear the costs himself whereas the benefits resulting from the infliction of sanctions (e.g., crime prevention) are

8 See, e.g., John Locke, Two Treaties of Government: Second Treatise section 13 (Cambridge University Press, ed. Peter Laslett, 1960).

${ }^{9}$ See Dennis C. Mueller, Public Choice II pp. 9-15 (Cambridge University Press, 1989). 
enjoyed by everybody. Consequently, individuals have sub-optimal incentives to inflict sanctions. ${ }^{10}$

This brief discussion is sufficient to illustrate that two of the most influential views concerning punishment, namely, certain influential versions of retributivism and deterrence theories fall under the category of instrumental theories. Some (although not all) retributivists argue that punishment is justified in order "to ensure that wrong-doers receive the suffering which they deserve." 11 Under this view, "necessarily acts of certain kinds have an intrinsic property that it is fit, appropriate or 'called for' that the perpetrator suffers for it." ${ }^{\prime 2}$ But there is no principled reason why the infliction of deserved suffering needs to be performed by the state. In fact: "if a wrong-doer suffers some natural calamity - especially if it is a consequence of her wrong-doing, or resembles the harm she had done to others - this may be seen... as "just what she deserves...",13 The same view concerning the role of the state in punishment is shared by other types of retributivists, for example, those who believe that punishment expresses punitive emotions such as resentment or indignation. ${ }^{14}$ In the view of "punitive emotions" retributivists, "certain wrongdoers quite properly excite the resentment (anger, hatred) of all right-thinking people, and the criminal law is a civilized and efficient way

\footnotetext{
${ }^{10}$ This is an argument in favor of the state inflicting the sanction or at least paying for its infliction but not necessarily determining its size.

11 See R. A. Duff, Trials and Punishments 198 (Cambridge University Press, 1986).

12 See Thomas E. Hill, Kant on Wrongdoing, Desert, and Punishment 18 Law and Philosophy 407, 425 (1999)

13 Duff, supra note 11 at 198 . For a clarification and defense of the claim that the guilty deserve to suffer, see Lawrence H. Davis, They Deserve to Suffer 32 Analysis 136-140 (1972). For a very careful articulation of desert theories, see Hill id at 413-414. Hill distinguishes between a practical or action-guiding desert theories and a merely faith guiding or wish-expression desert theories. The former argue that perpetrating crimes provide one a reason to inflict sufferings on the guilty while the latter argue merely that perpetrating crimes provides one a reason to wish that the guilty suffer. It is clear that a justification of punishment ought to be based on a strong, i.e., action-guiding desert theory.
}

14 See R. A. Duff, Punishment, Communication and Community 23-27 (Oxford University Press, 2001). 
in which such passions may be directed toward their proper objects, allowing victims to get legitimate revenge consistently with the maintenance of public order." ${ }^{15}$ To the extent that desert-based retributivists or the "punitive emotions" retributivists insist that it is the state rather than other agents that should inflict the deserved sufferings, it is simply because the state is well placed to determine what a person deserves and to inflict the sanction.

Deterrence theorists believe that deterrence depends on the probability of detection and the severity of the sanction. ${ }^{16}$ The agency of the state plays no essential role in the justification of punishment and consequently there is no principled reason to believe that non-state agents cannot inflict sanctions that will deter wrongdoers. In fact, deterrence theorists have often pointed out that non-state agents may be more effective than state agents in inflicting sanctions and that such sanctions may be more effective in deterring crimes. ${ }^{17}$

To conclude, justifying state-inflicted punishments on the basis of instrumental justifications requires two argumentative steps. First, one must establish that, in principle, inflicting sanctions for wrongdoing is appropriate or desirable. The infliction of sanctions of an appropriate magnitude fulfills an important role, e.g., the infliction of sufferings on those who deserve it or deterring or preventing crime. Second, one must establish that state-inflicted punishments are in fact the most effective means of inflicting the appropriate sanctions for transgressions. The criteria for the appropriateness of the sanctions can be based on considerations of justice, e.g., desert or they can be utilitarian. In both cases, however, the prospects of success in identifying and inflicting the

15 See Jeffrie G. Murphy, Jean Hampton, Forgiveness and Mercy 3-4 (Cambridge University Press, 1988).

${ }^{16}$ See Gary Becker, Crime and Punishment: An Economic Approach 76 Journal of Political Economy 169-217 (1968).

${ }^{17}$ Economic advocates of deterrence theories have often argued for the use of "bounty hunters" to detect crime. See, e.g., Mitchell Polinsky, Private Versus Public Enforcement of Fines 9 Journal of Legal Studies 105-127 (1980); Steven Shavell, The Optimal Structure of Law Enforcement 36 Journal of Law \& Economics 255-287 (1993). The advocates of shaming penalties also share the belief that privately-inflicted sanctions may be a better way of preventing crime. See references in supra note 1 . 
appropriate sanctions or the cost-effectiveness in performing this task (or other contingent advantages) provide the sole basis for determining who should have the power to inflict sanctions. Punishment can therefore be described as a task in search of an agent capable of performing it.

Normative preconditions arguments also maintain that punishment can be imposed by non-state agents. Furthermore, punishments inflicted by nonstate agents can in principle function in the same ways and be valuable for the same reasons as state-inflicted sanctions. Nevertheless, the advocates of normative preconditions justifications maintain that punishment inflicted by non-state agents is unjust for principled non-contingent reasons. A familiar argument along these lines maintains that punishment is designed to deter crimes, but that procedural considerations require that the severity of punishment be determined on the basis of a democratic deliberative process. It is thus unjust to inflict sanctions (even if these sanctions are "deserved" or produce efficient incentives) unless certain procedural preconditions are satisfied. These procedural preconditions require (at least under normal circumstances) the agency of the state. Another version of this type of justifications asserts that punishment is inherently a prerogative of the victim. The infliction of sanctions by the state is justified only when victims consent to transfer their power to inflict sanctions to the state. State-inflicted sanctions are thus just because the power to inflict sanctions was voluntarily transferred to the state by its citizens. In some passages of his famous discussion of punishment, John Locke argues in this vein that the consent of the governed to delegate their powers to punish is a necessary procedural requirement. ${ }^{18}$

The third type of justifications, the state-centered justifications for criminal sanctions, takes a more radical route and maintains that stateinflicted sanctions are fundamentally different from sanctions imposed by other agents. Although privately-inflicted sanctions may be desirable for various reasons, they are desirable for different reasons than state-inflicted sanctions. A useful analogy illustrating the nature of state-centered justifications is the blood feud. In a blood feud it is not the mere act of killing that counts; it is rather the performance of the killing by the appropriate agent, i.e., by a (male) member of the victim's family that

18 John Locke, The Second Treatise, supra note 887. 
counts. It is clear that in the bible it is only a specific member of the victim's family who had the right and responsibility to kill the slayer with impunity. ${ }^{19}$ The agent killing the murderer in a blood feud is not perceived as a means to perform the (allegedly just) act of killing; instead it is the act of killing which provides an opportunity for the appropriate agent to redress the injustice. A killing not performed by the appropriate agent does not therefore constitute blood feud and cannot redress the injustice. ${ }^{20}$

Joel Feinberg's theory of punishment is an example of a state-centered justification. Under his famous formulation of the expressive theory of punishment: "punishment is a conventional device for the expression of attitudes of resentment and indignation, and of judgments of disapproval and reprobation, on the part either of the punishing authority himself or of those 'in whose name' the punishment is inflicted." ${ }^{21}$ This function can only be performed by the state since "punishment expresses the judgment... of the community that what the criminal did was wrong." 22 In contemporary societies it is the state (and perhaps the state alone) that is understood to speak in the name of the community. Punishment of criminals performed by agents other than the state may of course deter wrongdoers, satisfy retributivist concerns and serve other important functions, but it does not have the same symbolic expressive significance that Feinberg believes punishment ought to have.

${ }^{19}$ See, e.g., Pamela Barmash, Homicide in the Biblical World 24 (Cambridge University Press, 2005).

${ }^{20}$ This implies that even if blood feud may serve some of the functions that in our society are served by punishment, e.g., desert or deterrence, there are fundamental differences between these practices. Punishment involves suffering of the person who perpetrated the crime. Blood feud involves inflicting death by a relative of the victim. In punishment, it is the agency of the perpetrator of the crime that counts while in blood feud, it is the agency of the person who inflicts the sanction that counts.

21 See Joel Feinberg, The Expressive Function of Punishment in A Reader on Punishment 74 (ed. R.A. Duff and David Garland, Oxford University Press, 1994).

22 Id at 76. Of course one could argue that a private sanction inflicted by individuals in the community may even better express the community's sentiments. It is not however my aim here to defend the position that the state speaks "in the name of the community," but only to point out theorists who defend state-centered justifications for criminal sanctions. 
Another influential example of a state-centered justification for stateinflicted sanctions can be traced back to Kant's discussion of punishment in the Metaphysics of Morals:

Even if a civil society were to be dissolved by the consent of all its members (e.g., if a people inhabiting an island decided to separate and disperse throughout the world), the last murderer remaining in prison would first have to be executed, so that each has done to him what his deeds deserve and blood guilt does not cling to the people for not having insisted upon this punishment; for otherwise the people can be regarded as collaborators in this public violation of justice. ${ }^{23}$

Under one plausible interpretation, Kant believes that the last murderer has to be executed before the dispersion of the society. ${ }^{24}$ An attempt to remedy the great injustice of not executing the murderer before the dispersion of the society could thus not be remedied by killing him after the dispersion of the society. For this would constitute a private act of killing rather than a public act of execution and, unlike a public execution, a private killing could not be done in the name of the people as a collectivity. The practice of state-inflicted executions of murderers is thus fundamentally different from a practice where murders are killed by nonstate agents. It is the difference in the identity of the agent which explains why the former act is required by justice, while the latter is prohibited.

23 Immanuel Kant, The Metaphysics of Morals 106 (Cambridge University Press, Translated and edited by Mary Gregor, 1996).

24 This conclusion follows from the interpretation given to this section by Thomas Hill. Hill believes that Kant's theory of punishment is a mixed theory. Establishing the practice of punishing wrongdoers is designed to protect freedom rather than to inflict deserved sanctions. Once this scheme is established, state officials are required to impose sanctions as prescribed by law, without deviating for pragmatic reasons. This section is understood by Hill to highlight the officials' duty to apply the law, i.e., to "reaffirm the idea that those responsible for enforcing the law must apply the legally prescribed sanctions without concern for whether punishment has any deterrent value in the particular case.” See Hill, supra note 12 at 433. After the dispersion of the state there are no officials who are charged with the responsibility of imposing sanctions prescribed by law. Hence the infliction of suffering cannot be justified as a part of the faithful fulfillment of the officials' duties. 
Note that the advocates of state-centered justifications for criminal punishments need not deny that some of the desirable byproducts of criminal punishments (e.g., deterring crimes, or inflicting deserved sufferings on the guilty) can be achieved by sanctions inflicted by nonstate agents. In order to be classified as an advocate of a state-centered justification for criminal sanctions, it is sufficient to maintain that stateinflicted criminal sanctions have some central functions which cannot, in principle, be realized by non-state agents.

The proposed classification of justifications of state-inflicted sanctions helps in providing a better understanding of the controversy identified by Fletcher. Some theorists uphold an instrumentalist view of state-inflicted sanctions. In their view, a complete justification of the practice of criminal punishment can be provided without reference to the agency of the state; the state being merely a convenient agent for performing a task which can be fully justified independently of the agency of the state. In contrast, advocates of both the normative preconditions justification and the statecentered justification argue that criminal sanctions cannot be justified without reference to the agency of the state. Criminal sanctions are political in essence; their understanding presupposes an understanding of the distinctive features of the state.

\section{IN DEFENSE OF A STATE-CENTERED Justification of CRIMINAl Punishment}

Section II investigated three types of justifications of state-inflicted criminal sanctions: instrumental justifications, normative preconditions justifications and state-centered justifications. In this section, I argue that state-centered justifications provide a more accurate account of our pretheoretical intuitions. Furthermore, I develop a sub-class of state-centered justifications which I call "integrationist justifications" for state-inflicted criminal sanctions. Under an integrationist justification, the successful exercise of the power to inflict sanctions depends upon a complex normative framework that comprises other state duties and powers. The power to inflict criminal sanctions is inextricably linked with the creation of prohibitions whose violations call for punitive measures. The power to inflict sanctions has to be a state power because of the interdependence 
between the state's power to create prohibitions and the power to inflict sanctions triggered by violating these prohibitions.

Sub-section A introduces the idea of an integrationist justification through the example of parent-children relationships. Sub-section B argues that an integrationist justification for the state's power to inflict criminal sanctions is consistent with some deeply seated pre-theoretical convictions. Then it develops an integrationist justification for state-inflicted criminal sanctions.

A. The Parental Power to Inflict Sanctions: An Integrationist Justification

This section explores the justification for parentally-inflicted sanctions. In particular it investigates the case for a "parent-centered" justification of punishment inflicted on children. It is important however to concede at the outset that this section is not aimed at conclusively establishing the soundness of a parent-centered justification. Instead, it aims to explore the structure of such a justification in order to facilitate the construction of an analogous argument in the political context.

A parent-centered justification of the punishment of children asserts that parentally-inflicted sanctions realize goals or perform tasks that cannot be successfully realized by non-parental agents. There is thus a fundamental difference between parentally-inflicted punishment and suffering inflicted on children by other agents (or natural forces). The successful infliction of punishments (or at least some types of punishments) hinges upon the identity of the agent who performs it.

To examine the plausibility of this justification compare it with an instrumental justification. At the center of such a justification would be the idea that punishing children is conducive to their education and promotes their well-being. Having established the desirability of inflicting sanctions, an instrumental justification would then point to the fact that parents typically love their children and are deeply interested their future wellbeing. Because of this a parent is more likely than other agents to punish a child under circumstances in which the punishment contributes to the child's well-being. 
This argument has some intuitive force and yet it fails to explain fundamental intuitions concerning parenthood. According to a deeply held belief, the power to inflict sanctions belongs "naturally" to parents and cannot be transferred to a third party without undermining the very institution of parenthood. In contrast to the instrumentalist justification, the parent-centered justification which sees parenthood as necessary for the successful infliction of sanctions can better account for this conviction. Depriving the parents of the power to inflict sanctions on their children and granting such a power to another agent would in effect transform that other agent into a quasi-parent and would deprive the "parent" of his or her natural parental responsibilities. ${ }^{25}$ Success in performing the parental tasks presupposes exercising the power to inflict sanctions and vice versa.

This view does not imply that one cannot think of new institutional arrangements under which the power to inflict sanctions would be shifted. Under one possible institutional arrangement, the community is responsible for raising children and every adult person has the power to inflict sanctions on them. By becoming quasi-parents members of the community take upon themselves new responsibilities and are granted new powers (other than the power to inflict sanctions). This transfer of the power to inflict sanctions from the "parents" to all adult members of the community can thus be seen as a partial transfer of parenthood from the "parents" to the community, and this will have far-reaching consequences. Under the alternative arrangement I envision, the transfer of power must include powers other than the power to inflict sanctions. Furthermore, such a view does not imply that parents have an exclusive power to punish their children. The integrationist justification could grant parents the exclusive power to punish children for certain types of misbehavior but

${ }^{25}$ To establish the alleged naturalness of parenthood think of a community in which parents are barred from inflicting sanctions on their children and the power to inflict sanctions is assigned to the parents' closest neighbors. Such a practice could be justified on the grounds that loving parents may be too soft and consequently that the sanctions they are likely to inflict on their children are too lenient. Neighbors, under this view, are less partial and more objective in their judgments concerning punishment. I suspect many would reject such a proposal as preposterous not merely because of the flaws in its factual premises. The resistance to such a proposal rests on the conviction that the power to punish "belongs" to the parents or that it is "natural" that parents are the ones who have the power to inflict sanctions and that stripping parents of their power to punish should be equated with stripping parents of parenthood. 
there is nothing in principle that prevents giving others the power to punish for other types of misbehavior. Last, such a justification does not preclude the possibility that the parents' powers to punish be constrained by the state in order to prevent abuse of that power, namely the infliction of punishment which does not serve the purposes for which the power was granted in the first place.

Can the conviction that the power to inflict sanctions naturally "belongs" to the parents be justified? Why should not the power to inflict sanctions be assigned to the agent who is most likely to exercise it properly? After all sanctions inflicted on children are designed to educate them and, while it is possible that parents are more likely to exercise this power in a way which is conducive to this purpose, there is nothing which, in principle, precludes the possibility that other agents would be more successful at this task.

One plausible defense of a parent-centered justification for granting parents the power to inflict sanctions is an integrationist defense. Under such a justification, parental duties and powers cannot be understood in isolation. Rather the powers exercised in punishing a child are affected by and, in turn, reflect on other parental duties and vice versa. The sentiments, convictions and judgments acquired in the course of inflicting sanctions are conducive to the fulfillment of other parental duties and the sentiments, convictions and judgments acquired in the course of fulfilling other parental duties are conducive to the rightful infliction of sanctions. It seems for instance that punishment of children inculcates in parents awareness that the children's well-being ought not to be equated with their immediate short-term pleasures. The parents' power to punish children is conducive to a better appreciation of what the well-being of their children consists of.

The conviction that the power to inflict sanctions "naturally belongs" to parents can now be seen as founded on the interrelations between different parental duties and powers. The power to inflict sanctions is "natural" to parenthood because having such a power and/or exercising it is conducive to the emergence of certain sentiments, to the maintenance of practices and to the formation of beliefs and judgments which are conducive to parenthood. Under this view, one must resist the temptation to look at punishment simply as a means of fulfilling an important task and then go 
in search for the agent who is the most capable of performing this task. Instead, one ought to regard parenthood as an important social institution for the sake of which one ought to assign tasks that contribute to the overall success of this institution. The appropriateness of sanctions and their success in achieving their goals thus depends on their being integrated with other aspects of parenthood. ${ }^{26}$ Parenthood and in particular the emotional and deliberative preconditions for being a good parent are thus the key to the understanding of punishment.

Here we have the outline of a justification for giving parents the power to punish their children. Under this justification, assigning the power to inflict sanctions to parents is not justified (or, at least, not primarily) justified on the grounds that the parents are the most capable of inflicting it successfully, but on the grounds that the power to inflict sanctions serves parenthood. Given that the institution of parenthood is a desirable institution and as such worth maintaining, it follows that one has reasons to create a normative framework necessary for parenthood and to assign the power to inflict sanctions to the parents.

To sum up, the integrationist justification for assigning parents the power to inflict sanctions analyzes parenthood in its totality as a complex relation which involves the fulfillment of duties and the exercise of powers. The appropriateness of assigning these duties and powers to an agent ought not to be judged separately. Instead, a complete account of parenthood ought to be based on an understanding of the mutual interrelations between these different powers and duties.

\section{B. An Integrationist Justification for State-Inflicted Sanctions}

Can a similar integrationist justification be provided for state-inflicted sanctions? Under such a justification, criminal punishment is not merely an important task in search of an agent capable of performing it; instead the infliction of criminal punishment is an integral part of successful statehood in the same way that the infliction of sanctions on children is

${ }^{26}$ The integrationist justification is hardly a novelty in the literature on parenthood. One influential argument suggests that the power to command and the duty to care are interrelated. See Saint Augustine, City of God Book XIX chapter 14 (Penguin Books, 2003). 
perceived by advocates of the integrationist justification as an integral part of successful parenting. The power to inflict criminal sanctions on wrongdoers is essential to the state because it is interrelated with other powers and duties of the state such that stripping the state of this power disrupts its proper functioning. The first sub-section points out some pretheoretical intuitions which support an integrationist justification. The second sub-section develops an integrationist justification for state's power to punish.

i) 1. Intuitions Supporting an Integrationist Justification for StateInflicted Sanctions

Several intuitive observations support the conjecture that the state's power to inflict criminal sanctions is grounded in an integrationist justification. The power to inflict criminal sanctions is a sphere of operation of the state which is almost universally perceived to be basic and fundamental. It is easy to conceive of a state that does not redistribute resources or one that does not maintain a tort law system. To imagine a society without a criminal law system or without a scheme of sanctions for the violation of norms is regarded often as tantamount to imagining a stateless existence. There are of course numerous other ways in which the state operates, but most of these seem to be more peripheral to the state's existence than the power to inflict sanctions for transgressions.

Furthermore, most people do not perceive privately-inflicted sanctions and state-inflicted sanctions as interchangeable. A criminal conviction may often give rise to (justified or unjustified) negative reactions on the part of private individuals. These negative reactions may in turn lead to the infliction of (justified or unjustified) privately-inflicted sanctions. There may be some sound prudential or moral reasons not to socialize with a person convicted of a crime. But privately-inflicted sanctions cannot substitute wholly or in part for state-inflicted sanctions following a criminal conviction. If criminal punishment could successfully be inflicted by non-state agents, state-inflicted criminal sanctions should arguably, as a matter of justice, be calculated in a way which takes into consideration the private sufferings of the criminal (or, at least, the private sufferings 
resulting from privately-inflicted sanctions). ${ }^{27}$ Yet, while courts sometimes take into account the private sufferings borne by the criminal, they are not obliged to do so. The private sufferings of the guilty (including private sufferings resulting from the infliction of privatelyinflicted sanctions) may lead courts to inflict a more lenient sentence out of compassion, but such leniency is discretionary and many theorists have opposed it. ${ }^{28}$ This indicates that state-inflicted sanctions are not typically viewed as commensurate with private sanctions. Privately-inflicted sanctions and state-inflicted sanctions are not merely two forms of commensurate sufferings which are added to each other. A possible explanation for the reluctance to conduct such a calculation is that private sanctions are "not imposed by the state, and whatever is not imposed by the state cannot be part of offender's punishment."29

Both of these observations can be easily explained within the framework of a state-centered justification. In a state-centered justification, the power to inflict criminal sanctions is understood to be essential to statehood such that stripping the state of this power frustrates the functioning of the state as such. The non-substitutability of privately-inflicted sanctions for stateinflicted sanctions also point to the fundamental role that the state as the agent in charge of inflicting sanctions plays in justifying the infliction of these sanctions. These considerations support a state-centered justification of criminal sanctions. This leaves open, however, the question of whether such a justification can be provided.

${ }^{27}$ Law and economics theorists have often advocated such a position. In the context of tort law, see, e.g., Robert Cooter \& Ariel Porat, Should Courts Deduct Non-Legal Sanctions from Damages? 30 Journal of Legal Studies 401-422 (2001)

${ }^{28}$ See, e.g., Richard Bierschbach Alex Stein, Overenforcement 93 Georgetown L.J. 1743, 1750-1752 (2005). Even theorists who support the substitutability of state-inflicted and privately-inflicted sanctions concede that this is not the general view. See, e.g., Douglas Husak, “Already Punished Enough” 18 Philosophical Topics 79 (1990). An interesting indication to the reluctance to take into account sufferings resulting from privatelyinflicted sanctions can be found in German criminal law. Section 51 of the German Criminal Code entitled "crediting" requires courts to deduct sanctions imposed by courts for the same offense, but it does not indicate that privately-inflicted sanctions ought to be deducted. The German criminal code differentiates sharply between state-inflicted sanctions and privately-inflicted sanctions.

${ }^{29}$ See Husak, id at 85 . Husak himself however rejects this view. 
ii) 2. Why Only the State Can Inflict Criminal Sanctions?

Some opponents of privately-inflicted criminal sanctions argue that a delegation of the power to inflict sanctions to private individuals raises serious pragmatic concerns. ${ }^{30}$ I wish however to raise a principled argument against such a delegation - an argument which suggest that even if the pragmatic concerns can be overcome, such a delegation is nonetheless impermissible.

The most fundamental task of the state is the task of governing justly. Just governance requires the state to govern its citizens under constraints dictated by justice. Just governance presupposes the guidance of behavior and the issuing of prohibitions. Note that the integrationist justification provided here is premised on the assumption that the state is justified in issuing prohibitions and that the violation of these prohibitions justifiably triggers the infliction of sanctions. The integrationist justification aims to show that when these conditions are satisfied, the state and the state alone ought to make determinations concerning the severity of these sanctions and then inflict them. The state being the initiator of criminal prohibitions cannot thus delegate the powers to determine the severity of the sanction or to inflict it to private entities.

One unsuccessful attempt to develop an integrationist justification of statesanctions is that of Anthony Duff. In his view:

The criminal law declares certain kinds of conduct to be wrong - to be criminal. But if the law, or the society in whose name it speaks, is to mean what it thus says, it is committed to censuring those who nonetheless engage in such conduct. To remain silent in the fact of their crimes would be to

\footnotetext{
${ }^{30}$ Pragmatic concerns were often raised against shaming penalties. There are many who believe that shaming penalties are erratic and unreliable. See, e.g., Stephen P. Garvey, Can Shaming Penalties Educate 65 University of Chicago L. Rev. $748-749$ (1998). Others have pointed out that the more criminals are detected, the lesser the effectiveness of shaming penalties is. See Alon Harel \& Alon Klement, The Economics of Stigma: Why More Detection of Crime May Result in Less Stigmatization (forthcoming in 36 Journal of Legal Studies).
} 
undermine - by implication to go back on—its declaration that such conduct is wrong. ${ }^{31}$

Duff believes that the prohibitions enacted by the state have implications beyond their mere ceremonial verbal declaration, namely, that the state is wiling to censure behavior which conflicts with the prohibition. To remain silent, i.e., to fail to inflict sanctions casts doubts on the sincerity and seriousness of the moral commitment of the state and consequently undermines its authority. Put differently the willingness to inflict sanctions buttresses the state's moral commitment to the norms it declares to be obligatory. The power to issue prohibitions and the power to inflict sanctions for their violation are thus closely interrelated. Assigning the power to issue prohibitions without also assigning the power to inflict sanctions undercut the state's moral authority by casting doubts on its sincerity and moral commitment.

Unfortunately this justification does not succeed. Failing to inflict sanctions does not necessarily (or even typically) cast doubts on the sincerity or the moral commitment of the state. To see why, think of the traditional utilitarian reasoning concerning punishment. Utilitarians argue that punishment is justified only when inflicting it maximizes utility. A failure on the part of a utilitarian to inflict sanctions for wrongdoing when the infliction of these sanctions does not contribute to the maximization of utility does not indicate insincerity on the part of the utilitarian. On the contrary, such a failure indicates a faithful adherence to utilitarianism.

Furthermore, if the state can be sure that the sanctions will be inflicted privately, then a failure to inflict sanctions does not show a lack of moral commitment on the part of the state. This is certainly the case when the state sustains and reinforces the mechanisms for privately-inflicted sanctions as the advocates of shaming penalties urge it to do. As long as the state guarantees that sanctions will be inflicted either by its own officials or by delegating the power to reliable non-state agents, the state conveys serious commitment to the prohibitions it issues.

${ }^{31}$ Duff, supra note 14 at 28. 
Let me provide a different integrationist argument. This argument is meant to establish that criminal sanctions ought to be grounded in state's judgments concerning the wrongfulness of an act and the appropriateness of the sanctions. Privately-inflicted sanctions, under this argument, are grounded in the private judgments of those who inflict them. They sever the link between the state's judgments concerning the wrongfulness of the act or the appropriateness of the sanctions and the infliction of the sanction and, furthermore, I will show that, privately-inflicted sanctions are impermissible for that reason. It is impermissible on the part of the state to authorize private individuals to inflict suffering on the guilty.

To establish the impermissibility of privately-inflicted sanctions assume a law-abiding citizen $\mathrm{A}$, who is asked (or hired) by the state to inflict sanctions on convicted offenders. The state asks A to ostracize persons convicted of a particular offense. Upon being notified about the conviction of person B for this offense, A considers whether she ought to participate in the sentencing scheme by ostracizing B or limiting her social interaction with B.

It seems that A's decision to ostracize B could be based on three possible reasons. Ostracizing $B$ could be based: i) on A's judgment that ostracizing B is a way of fulfilling A's civic obligations; it could be based ii) on A's judgment that $\mathrm{B}$ committed an offence and deserves to be punished and it could be based iii) on A's trust that the state made an accurate determination concerning the wrongfulness of B's behavior and the appropriateness of the sanction. In the third case, A does not form an independent judgment with respect to these issues. In each one of these cases I will discuss two separate issues. First I will discuss the question of whether ostracizing B can count as punishment and second I will discuss whether it is permissible (either on the part of the private individual to inflict the sanction or on the part of the state to authorize such an infliction).

Ostracizing B as a way of fulfilling one's civic duties is of course harmful to $\mathrm{B}$ but it is not properly classified as a criminal punishment since it does not presuppose a judgment on the part of A that B has committed a wrong. Punishment, after all, involves the infliction of suffering grounded in a 
particular reason, namely that a wrong has been perpetrated. ${ }^{32}$ Inflicting suffering as a means of fulfilling one's civic duty does not presuppose a judgment by A concerning the prior commission of a wrong on the part of the criminal.

Is it permissible for $\mathrm{A}$ to inflict suffering on $\mathrm{B}$ in order to fulfill his or her civic duty and to do it under circumstances in which A has not formed an opinion concerning the wrongfulness of B's behavior? To establish the impermissibility of such an act think of the grievance which $B$ can raise against $\mathrm{A}$. Most convincingly, $\mathrm{B}$ can argue that it is unjust on the part of $\mathrm{A}$ to inflict a suffering without forming a judgment that $\mathrm{B}$ committed a wrong. A's assertion that he merely fulfills a civic duty implies that $\mathrm{A}$ is willing to inflict this suffering irrespective of whether B has committed a wrong. It seems evident that there can be no civic duty to inflict suffering under these conditions.

Assume now that A ostracizes B because she formed the opinion that $\mathrm{B}$ has committed a wrong and deserves to be punished. This is indeed a punishment for wrongdoing but A's judgment concerning the wrongfulness of B's behavior and the appropriateness of the sanction is a private judgment on the part of $\mathrm{A}$. The sanction does not reflect a judgment on the part of the state concerning the severity of the offence or the appropriateness of the sanction. The person inflicting the sanction may of course happen to form an opinion on these matters identical to that of the state. But this would be a happy coincidence and would not transform the private infliction of suffering into a state punishment.

But is A's infliction of suffering in this case impermissible? As long as A's judgment is a private one made by $\mathrm{A}$ on the basis of her own judgment, it may be permissible. Yet, it is wrong on the part of the state to approve of the infliction of the sanction under these circumstances. To establish the impermissibility of the state's support for A's action, B could simply argue that the state may not simply endorse A's judgment concerning the wrongfulness of B's action. It would be wrong on the part of the state to grant A's private judgment greater weight than B's private

32 All conventional definitions of punishment include reference to such a requirement. See, e.g., Hart, supra note 4 pp. 4-5 (1968) 
judgment concerning the wrongfulness of B's behavior. Instead the state ought to make its own public judgment concerning the wrongfulness of B's action and its ramifications. B has a legitimate grievance if she is subjected to A's state-authorized private judgment and this grievance is distinct from any grievance she may have in being subjected to an (unjust) public judgment.

Assume finally that A ostracizes B not because she believes it is her civic duty or because she forms an independent judgment concerning the wrongfulness of the act and the appropriateness of the sanction. Instead, A inflicts the sanction because she trusts the state's judgment on these matters. It seems that sanctions inflicted on the basis of such trust are grounded in the state's own judgments and can thus be regarded as criminal sanctions proper. The trustworthy citizen does not form an independent judgment concerning the wrongfulness of the action or the appropriateness of the sanction determined by the state. She simply functions as an instrument for realizing the state's own judgments.

But, it is doubtful whether such trust could be ever justified. If such trust could be justified, the citizen would be exempted from responsibility for the infliction of an inappropriate sanction. The moral responsibility for inflicting such a sanction would rest with the state. Such an exemption from moral responsibility is sometimes justified with respect to state officials such as judges, prison guards or perhaps even executioners. Citizens however are different. They cannot abdicate their responsibility when suffering is inflicted.

Consider an example of a person who opposes capital punishment. Such a person, no doubt, should resist the state's invitation to execute an offender on the grounds that he believes that capital punishment is not an appropriate sanction. A private person who accepts the state's invitation and inflicts such a sanction cannot escape moral responsibility by pointing out that the state asked him to do so.

Inflicting a sanction under these circumstances exposes the perpetrator of the crime to a serious risk. Judgments concerning the appropriateness of sanctions for wrongdoing are highly contestable. A citizen who is asked by the state to inflict sufferings on a criminal should not rely on the state's judgments when the consequences are so grave. The citizen is required in 
this situation to form a judgment concerning the appropriateness of the sanction she is to inflict. If she fails to do so and, if, as a result of her unquestioning conformity with the state's judgments, she inflicts an inappropriate sanction, she is accountable for her failure. Inflicting the sanction in these circumstances should therefore to be regarded as a private act on the part of the citizen founded on the citizen's own judgment that the sufferings inflicted are appropriate. Failing to form an independent opinion concerning the appropriateness of the sanction does not transform the act from a private into a public act and does not turn it into a state sanction.

The status of a citizen who is called upon by the state to inflict sanctions thus differs from the status of an official. A judge, a prison guard or even an executioner is often entitled or obligated to faithfully execute the state's sentencing decisions. Such a duty to execute the state's sentencing decisions is not boundless but it is much broader than the duties borne by a citizen. Demarcating the boundary between citizens and officials is not always easy, I admit, but it is this line which explains the difference in the moral responsibility of a judge or a prison guard on the one hand and of a citizen who is asked by the state to participate in the infliction of privately-inflicted sanctioning on the other. The former is an official who is typically entitled or even required to perform this task irrespective of his private convictions concerning the appropriateness of the sanction; the latter bears moral responsibility for what she does irrespective of whether she follows the state's sentencing guidelines.

To conclude, the integrationist argument maintains that the power to issue prohibitions and the powers to make determinations concerning the severity of the sanctions and to inflict them are inextricably interrelated. It is impermissible on the part of individuals to inflict sanctions without forming an independent judgment with respect to the wrongfulness of the action and the appropriateness of the sanctions. If they form such a judgment it is impermissible for the state to endorse that judgment. To the extent that criminal sanctions are justified, they therefore have to be inflicted by the same agent who creates the prohibitions. The suffering inflicted by privately-inflicted sanctions is grounded in a private judgment concerning the wrongfulness of the act or the appropriateness of the sanction. By privatizing the infliction of the sanction, the state effectively transfers not merely the "technical" power to execute the sanction. Instead, 
it strips itself of the power to make binding determinations concerning the wrongfulness of the act and the appropriateness of the sanction. These determinations should instead be attributed to the individual who inflicts the sanction rather than to the state. By delegating this power to private individuals, the state in effect severs the link between the prohibitions it issues and the suffering inflicted on the offender. The individual who inflicts punishment on the basis of reasons he has acquired from the state acts on what she has come to believe and has judged to be a sufficient basis for action. The contribution to the genesis of his action made by the state's invitation to participate in the infliction of sanctions is, so to speak, superseded by the agent's own judgment. ${ }^{33}$ The suffering of the criminal is therefore a "private" suffering - a suffering founded on a citizen's judgments concerning the wrongfulness of the act and the appropriateness of the sanction.

The infliction of state-initiated privately-inflicted sanctions is impermissible. It is impermissible on the part of a citizen to inflict sanctions without forming an independent judgment concerning the wrongfulness of the alleged wrongful act. When such a private judgment has been formed, it is impermissible on the part of the state to approve of the infliction of the punishment since such an approval gives undue weight to the private moral convictions of the individual who inflicts the sanction. Furthermore, the belief that the sanctions for wrongdoing should reflect the state's judgments concerning the wrongfulness of the act is quite fundamental to what we think of as a legal system. Instituting privatelyinflicted sanctions would thus challenge fundamental assumptions of the legal system. Under these assumptions criminal sanctions ought to be grounded in societal judgments generated by social and political deliberation.

33 This way of articulating my claim is borrowed from the discussion of Scanlon's defense of freedom of speech. See Thomas Scanlon, A Theory of Freedom of Expression 1 Philosophy and Public Affairs 204, 212 (1972). 


\section{CODA: A CRITIQUE OF CONTEMPORARY Punitive Practices}

Some of the most heated contemporary controversies in criminal law are grounded in conflicting intuitions concerning the role of the state. This section investigates two contemporary debates: the extensive use of shaming penalties and private prisons. These two issues involve two different forms of privatization. Shaming penalties privatize both the determination of the severity of the sanction and the infliction of the sanction. The agents who shame select the sanctions they wish to inflict (within the boundaries of the law) and they are also in charge of inflicting these sanctions. In contrast, the corporations operating private prisons inflict sanctions whose severity is determined by the state.

\section{A. Shaming Penalties}

Stigmatization imposes costs on offenders by identifying them and disseminating information about them. This in turn generates social and professional isolation and alienation from the rest of society. Potential wrongdoers are deterred because other individuals, law-abiding individuals in particular, might limit their social or professional interaction with them as a result of their conviction. Shaming penalties presuppose the active cooperation of private individuals. Such cooperation is needed because effective stigmatization requires that individuals distance themselves from the offenders and isolate them personally or professionally.

This aspect of shaming penalties was diagnosed and condemned in James Whitman's vigorous attack on shaming penalties:

However much prisons may have declined into chaos, they are in principle controllable. However monstrous they may have become, we all agree that the state has the duty to manage them: to establish rules, to call review boards, to answer complaints in court. None of that apparatus exists to control the enforcement of shame. This means that though courts may wish to abandon the prison system and switch to a system of shaming, they must not be permitted to do so. Doing so means 
abandoning their obligation to maintain a monopoly of the means of power-it means abandoning their duty to be imposers of measured punishment. ${ }^{34}$

Whitman's opposition to shame penalties is motivated by the sense that the state ought to maintain the exclusive power to punish irrespective of any instrumental considerations. In Whitman's view a delegation of this power to the community deprives the criminal of his dignity irrespective of the severity of the sanctions that the community chooses to inflict on him. Whitman thus argues that the state's control over the infliction of sanctions is grounded in the state's duty to be "the imposers of measured punishment. ${ }^{, 35}$

Yet, Whitman fails to provide reasons for his assertion that only the state ought to control the infliction of sanctions. Advocates of shaming penalties do not have to accept Whitman's dogmatic view that delegating the power to inflict sanctions means abandoning the state's "obligation to maintain a monopoly of the means of power-it means abandoning their duty to be imposers of measured punishment." Such an advocate could question whether by introducing shaming penalties the state indeed abandons its monopoly on power and whether it has an obligation to maintain such a monopoly in the first place.

The integrationist justification may provide the missing rationale for Whitman's powerful opposition to shaming penalties. Shaming penalties, as currently practiced in the US, constitute a highly deficient privatelyinflicted scheme of sanctions. Shaming penalties are often inflicted for the wrong reasons. Individuals who inflict shaming penalties are often instrumentally-motivated. ${ }^{36}$ In some cases the hostile reactions take place when the commission of the offence is indicative that the goods or services that are likely to be provided by an offender are inferior to those

34 See James Q. Whitman, What is wrong with Inflicting Shame Sanctions? 107 Yale L.J. 1055, 1091 (1998).

${ }^{35}$ Whitman, id 1091.

${ }^{36}$ See Harel \& Klement supra note 30. 
that are likely to be provided by non-offenders. ${ }^{37}$ In such cases the suffering inflicted on the criminal is merely a price reflecting the inferior quality of the goods or services rather than a genuinely punitive measure. But even when ostracizing the offender is based on a judgment that the offender has committed a wrong, this judgment is a private judgment on the part of those who ostracize, and it would thus be wrong for the state to grant its approval to this judgment; more specifically, it would be tantamount to granting undue weight to the judgment of the individual or private entity who inflicts the penalty.

\section{B. Private Prisons}

The emergence of private prisons has sparked a heated debate. For the most part this debate focuses on the relative efficiency of private prisons as compared to their publicly run counterpart. ${ }^{38}$ Yet some critics of private prisons challenge the legitimacy of these prisons. These critics share the view that the act of incarceration is "intrinsically governmental in nature" and that, as a consequence, a recourse to private prisons is inappropriate regardless of the relative efficiency of this penal form. ${ }^{39}$ An example can be found in Michael Walzer's work:

Police and prison guards are our representatives, whose activities we have authorized. The policeman's uniform represents his representative character. When he puts his uniform he strips himself bare, so to speak, of his private opinions and motivations. Ideally, at least, he is equally energetic in enforcing laws that he does and does not like and

\footnotetext{
${ }^{37}$ See Richard Posner, and Eric Rasmusen, Creating and Enforcing Norms, With Special Reference to Sanctions. International Review of Law and Economics 19(3): 369, 371 (1999).

38 See Sharon Dolovich, State Punishment and Private Prisons 55 Duke L.J. 437, 441 (2005).

39 For an examination of this claim, see Douglas C. McDonald, Public Imprisonment by Private Means: The Re-emergence of Private Prisons and Jails in the United States, the United Kingdom, and Australia 34 British J. Criminology 29, 39 (1994).
} 
he treats all citizens, and all criminals, in the same way, whatever his personal prejudices. ${ }^{40}$

Walzer further argues that the profit motive "exposes the prisoners to private or corporate purposes, and it sets them at some distance from the protection of the law." 41 Walzer thus worries that private prisons are operated by agents who are not motivated by the right sort of reasons. His concern is that it is unjust to expose prisoners to treatment governed by profit considerations.

The main argument of this paper leads to the conclusion that even if the running of private prisons was not dominated by profit-motives, prisons cannot in principle be operated by private entities. These entities have a duty to make independent judgments concerning the wrongfulness of the act and the severity of the sanctions and those judgments are never judgments which can justify the infliction of state-approved privatelyinflicted sanctions.

The examples of shaming penalties and private prisons demonstrate that the debates concerning the justification of state-inflicted sanctions are not merely theoretical. Even if a solely privately-inflicted scheme of sanctions is not a realistic option, there are currently reforms or reform proposals to grant private individuals the power to inflict sanctions for wrongdoing. These proposals have often been initiated and discussed by economists, sociologists and lawyers. This paper establishes that philosophical considerations provide reasons to oppose schemes of privately-inflicted sanctions.

40 See Michael Walzer, At McPrison and Burglar King, It's...Hold the Justice, New Republic, Apr. 8, 1985 at 11. Somewhat inconsistently with his statement concerning the importance of public officials, Walzer suggests to use nongovernmental entities to perform some prison-like sanctions. See id at 12 .

41 See id at 12. 